\title{
The Role of Legal Forms in Professional Football
}

\author{
Zoltán Imre Nagy \\ Óbuda University \\ Népszínház u. 8, H-1081 Budapest, Hungary \\ nagy.imre.zoltan@kgk.uni-obuda.hu
}

\begin{abstract}
In the event of a professional football club the fundamental sports objectives can get into contradiction with the intentions of the investor, who might wish, in many cases, to take care primarily for the increase of profits instead of serving the aims of football and the most important designation of a football club. In my study you will find an analysis of legal forms for football clubs, as well as the method of the management by owner determined primarily by such forms. We keep in mind primarily the aspect how these forms influence the possibilities of financing and the acquisition of capital. A form of entrepreneurship and management which takes into account the possibilities of a football club allows for the implementation of the most important objectives of sports, even if it is necessary to involve a considerable amount of capital. Through transportation into an incorporated firm with the appropriate shaping and operation of a group of companies, the aims of capitalisation will also be pursued, while the sports objectives remain the primary ones. (Such forms are limited liability companies, limited partnerships, share companies, registered associations, etc.) On the basis of foreign experience our study intends to make findings and proposals in order to serve establishing and operating such forms of enterprises, which will create - in addition to the priority of sports objectives - also broad possibilities for capitalisation in professional football.
\end{abstract}

Keywords: cost, football capital-company; capital; legal form of Business; Registered Association; Ltd; Share Company

\section{Introduction}

A rather big part of professional football clubs may be characterised by a permanent process of structural and management transformation, which comes to expression in the variation of the legal forms of undertaking in professional football, and, moreover, in the phenomena of up-to-date controlling, planning, risk management and financial management. ([7] Nagy, Z. I. 2011). With the help of such modern elements, football clubs start building up a specialised branch, up-todate and complex from an economic viewpoint, in which the most important 
requirement will be to secure the requisites of licence until the end of the championship. Here, liquidity reserves have high priority importance, while the analysis of indebtedness is relegated to the background even in the course of judging the licence requirements. In accordance with the regulations of UEFA, any possible insolvency must be prevented, for many years, in each country, through making very high requirements, during the season and championship. These strict regulations pose a challenge even for the most highly developed football countries; thus, for example such regulations are not entirely enforced even in Germany. Thus, the equality of financial chances highlighted by UEFA is realised only to a restricted extent in respect of all European football clubs. Based on the always expanding business activity of various football clubs, the permanent constraint of adapting themselves to the requirements of global economy generates more and more significant financial and economic restrictions against football clubs. Thus it is to be stressed that the Basel II Directive considerably influences the funding of football clubs on the side of credit institutions, although professional football is impacted in this process only indirectly. At the same time, the evaluation and examination of credit standing and the credit rating have become highly important for business enterprises operating in professional football. Of course only those football clubs functioning with permanently positive results can meet such an acute challenge, since they are capable to improve their credit rating on a regular basis. In contrast, the football clubs having an unfavourable credit rating might get into very difficult circumstances in consequence of such a credit rating. This may even result in their getting no credit at all. For example, the strict regulations do not cause any problem for the football clubs with licence; in their case an essential improvement of credit rating can be found on a continuous basis, which is a true index of economic consolidation.

\section{Importance of the Legal Form of Football Clubs}

In line with the international outlook I wish to rely primarily on the peculiarities of German professional football, since it shows most of all the presumable mainstream of the development of football. Let us overview which are the forms of undertaking in the German League football, and what the changes in trends are.

On the basis of the 1998 Resolution of the German Federal Parliament, it is possible to operate football undertakings also in the form of an incorporated firm [ which means that the members are not responsible for the liabilities of the company; these are share companies, limited liability companies, and limited share partnerships], in addition to the classical form of association ([3] Bundesliga Offizielles WEB-Seite 2011). The main point here is that such part of the association participating in League football can be outsourced into the form of incorporated firm. It is interesting that in Germany 21 teams from League I and 36 teams from League II are operating currently in the form of incorporated firms. 
The change in legal forms, i.e. the transformation from the traditional form of association into an incorporated firm, has accelerated and has become prominent over the past number of years. Nevertheless, registered associations continue to play an important part in the Leagues, since this form is functioning even directly in the Leagues, but it continues to remain in the foreground also as parent company of incorporated firms.

$\begin{array}{llll}\text { Legal Form } & \text { Frequency } & \text { Legal Form } & \text { Frequency } \\ \text { Association } & 15 & \text { LLC with right } & 5 \\ \text { Share comp. } & 2 & \text { LLC \& Co.LP. } & 10 \\ \text { LLC } & 4 & \text { I.-II Liga, Total } & \mathbf{3 6}\end{array}$

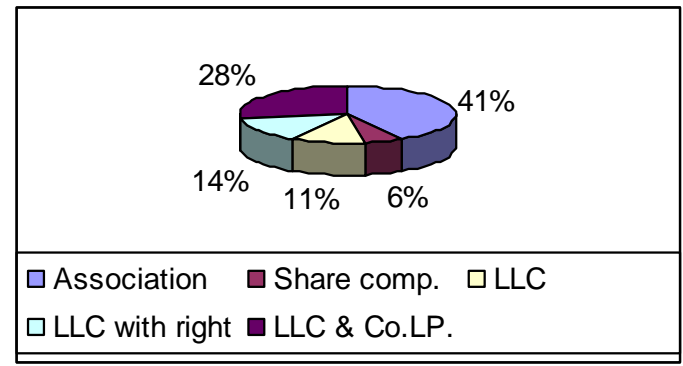

Figure 1

Distribution of legal status in Germany (I and II. League clubs)

Source: [5] Dworak, A.: Finanzierung für Fußballunternehmen, Erick Schmidt Verlag 2010, p. 52

\section{Advantages and Disadvantages of Registered Association}

The determining element of this legal form is the public purpose (non-profit goal) even in Germany. The associations have a public target even in the field of football, and thus they are subject to the effect of the law of associations. The management and the supervisory board are elected by the members of the association at the members' meeting. In Germany, 90,000 associations are functioning with a membership of 24 million, mainly in the fields of mass (recreational) sports/amateur sports. The side of revenues of the annual budget consists mainly of the payments of membership dues, state subsidies and donations, but even business activity may be pursued as an ancillary activity in the interest of increasing the revenues, provided this serves the public purpose. In Germany, associations were able to manage their finances at an average of EUR 49,000 in the past years at the annual level; however, half of the sports associations were operating with a budget of EUR 14,000 on average [7] Nagy, Z. 
I., 2011). The more important clubs manage a significantly higher budget, and this results, in the case of small clubs, in a considerably negative deviation from the average and in the high frequency of such deviation.

Funding, registering and operating an association is relatively simple, and the rules are transparent. All strata of society like to make use of the advantages of this form of non-profit company having legal personality, which provides tax benefits. The registered associations fill such an important social role in Germany that they are exempted, in respect of the public purpose activity, from corporate income tax, industrial tax, real estate and property tax, and in addition, they are only charged by a beneficial $7 \%$ general turnover tax (VAT). Otherwise, the general rate of VAT is $19 \%$. However, these tax benefits touch professional football undertakings to only a minor extent as these professional associations may obtain only a small amount of revenues exempt from taxation. The tax benefit helps mostly amateur and mass sports ([4] Bundesligareport (2011).

It is a disadvantage that the members of the association may exercise rights of control to a limited extent only, since the management is only obliged to satisfy the members' need for information essentially at the members' meetings ([8] Schmid, V. Unternehmensführung im Profifußball). Also the depth of information and orientation is insufficient. Apart from the above, the members have practically no possibility for obtaining information. The associations' supply of business information may not be compared even remotely with the requirements governing incorporated firms. In the event of a bad impression obtained by a member of the association at the members' meeting in connection with business management, he will have first of all the possibility of withdrawal, and, if the dissatisfaction of members becomes overwhelming, the issue of winding up of the association may be raised. However, the member of an association will never reacquire, in any of the cases above, his or her paid-in contributions, and thus the only possibility remaining for him or her is to trust blindly in the work of the association's management.

It is a further deficiency in the operation of the form of association that there are no regulations for the application of profits. Consequently, the earned profits are spent on increasing the value of the roster of players in most of the football clubs, and they pay much less attention to forming financial reserves, although this could be very useful later on from the point of view of long-term operations.

The rules relating to associations do not provide satisfactory protection even for lenders. Associations are answerable with their own assets for their liabilities, but there are no detailed legal prescriptions in the relevant law of associations in Germany. Of course, in principle, regulations may be set up relating to publicity, application of profits and collateralising the loans in the statutes of associations, which is, however, scarcely feasible. We can hardly suppose that the elected management of an association would set up restrictions on itself. Logically, all this has a negative impact on the opportunities for financing with outside capital. 
It follows from all this that a registered association may only make use to a restricted extent of any potential possibilities of financing. An increase in equity is allowed primarily through the retention of profits, but we must add that the profits may only be increased up to a certain limit per year, in order to maintain the nonprofit status of the company. The hosting of shares and the involvement of contributed capital may only be secured after transformation into an incorporated firm. Therefore, in the event of associations, funding by banks or private individuals who are committed to the given association will be possible in line with own revenues and subsidies. The first-mentioned resources may cover current expenditures to a minor extent; they play a part mostly in the financing of longterm projects. Due to the aforementioned lack of publicity and of mechanisms of control and protection, the issuance of bonds or of the so-called participation certificates poses difficulties to associations.

Altogether we can state that the registered association will continue to function as one of the most significant legal forms of professional football in Germany as well, in spite of the fact that the law of associations is far from providing satisfactory conditions for the operations of football clubs carrying out modern business activity. Thus, it is no wonder that in Germany there appears a strong inclination towards the transformation from the form of association into the form of incorporated firm. This does not mean that the clubs (mainly the amateur and mass sports clubs) will turn away from the form of association. Here we should rather mention the trend that the fields and branches, where up-to-date conditions of business management make this necessary, must be subject to the process of transformation (through becoming an incorporated firm via outsourcing from the association). Professional football is such a field.

In Hungary, there is a need for finding the appropriate form of motion in order to secure that vision, and the practice of entrepreneurship should gain ground in spite of the fact that sports leaders, audiences and authorities have grown up in an attitude ruled by the form of association ([1] Bács, Z.-Szima, G. 2012).

\section{Registered Association: VfB Stuttgart, Germany (Very Successful Functioning)}

This famous club was founded in 1893 and is one of the founders of the German Professional League, where, in 1975, huge financial tensions were generated in consequence of the then president's exaggerated and over-dimensioned concept of investment and purchase of players. As a result, the club dropped out from the First League, but it came back in 1976, and it reached even the fourth place. In parallel with the successful participation in the championship, they succeeded in enlarging also the infrastructure, with a new club centre built by the middle of the 80 s. 
The club gained the championship four times, in Season 2006/07 for the last time, when the team also won the German Football Cup. In contrast to many professional football clubs, Stuttgart did not build a structure of an incorporated firm, but, essentially, it preserved the form of registered association. Several business areas were outsourced over the past years, but these remained profit centres operating under the direction of the association. The licence right remained with the association.

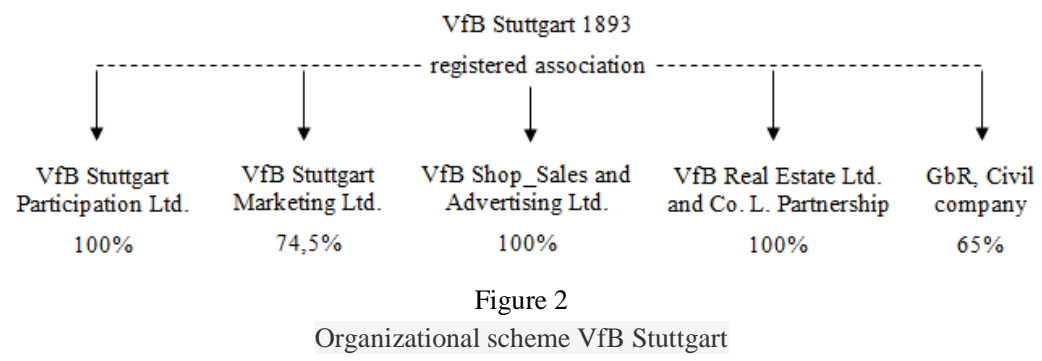

Source: [8] V. Schmid, Unternehmensführung im Profifußball, Berlin 2004

Proprietary association: VfB Stuttgart Registered Association. The task of VfB Stuttgart Holding LLC is the development of alternative solutions for financing, e.g. the involvement of investors functioning as dormant partners. The task of VfB Stuttgart Marketing LLC is operating the professional football division, and as a compensation it receives an agent's commission from the association, in a manner basically similar to an external agent selling external rights. The task of VfB Shop Sales and Advertisement LLC is organisation and arrangement of merchandising. The task of VfB Property GmbH \& Co. KG [limited partnership with an LLC as general partner] is the management of leaseholds and real estate for the association. The GbR (civil law association) is a simple form of undertaking widespread in Germany, based on a specific contract of agency.

The traditional form of association as a basic model of management may also be successful in professional football, but it is true that this is realised also thanks to Stuttgart's main sponsor, its exclusive partners and its team partners. The list is deserving of attention: Gazi, Merzedes Benz, Puma EnBW, Kronbacher, BW Bank, Breuninger, Kärcher, and Coca Cola. Therefore, is no wonder that VfB Stuttgart was and is very successful.

Records of VfB Stuttgart:

German championship:

- Winners (5): 1950, 1952, 1984, 1992, 2007

- Runners-up (4): 1935, 1953, 1979, $\underline{2003}$

German Cup:

- Winners (3): $\underline{1954}, \underline{1958}, \underline{1997}$

- Runners-up (2): 1986, 2007 


\section{German Super Cup:}

- Winners (1): 1992

German League Cup:

- Runners-up (3): 1997, 1998, 2005

Oberliga Süd I:

- Winners (3): 1945-46, 1951-52, 1953-54

- Runners-up (3): 1949-50, 1952-53, 1955-56

$\underline{2^{\text {nd }} \text { Bundesliga Süd II: }}$

- Winners (1): 1977

Bezirksliga Württemberg-Baden:

- Winners (2): 1926-27, 1929-30

- Runners-up (1): 1925-26

Gauliga Württemberg:

- Winners (4): 1934-35, 1936-37, 1937-38, 1942-43

- Runners-up (4): 1938-39, 1939-40, 1940-41, 1941-42

UEFA Cup:

- Runners-up (1): $\underline{1988-89}$

UEFA Cup Winners' Cup:

- Runners-up (1): 1997-98

UEFA Intertoto Cup:

- Winners (2): $\underline{2000}, \underline{2002}$

Accordingly, the corporate philosophy of the association is conservative and successful, if we consider the achievement of sports results to be the main objective. This creates the foundations for success also in the economic field, i.e. a safe economic background must be underpinned by successful sports results. This statement raises the question as to the proper tangible and intangible results of sports.

If we have a closer look, however, we can see that this rather simplified objective cannot be a strategic guideline in this new dimension of modern football, which in recent years has shown extraordinary development and today confronts football enterprises with global challenges ([2] Bott, S. 2007). Naturally, the main objective of football enterprises is also complex, made up of specific systems of sub-goals. A thorough examination and analysis of subordinated goals contribute to determining the ultimate objective itself and provides particular help in achieving this. The aggregate system of objectives in the case of a football enterprise is made up of three components: sports results, economic results and 
intangible results (value). These three components can substitute each other only to a limited extent and strongly correlate with each other. By breaking down the objectives that form the basis of enterprises into components, they can be determined and optimised more precisely, as separate calculations can be prepared for each and every result component and each element therein ([1] Bács, Z.-Szima, G. 2012, [11] Borbély, A 2112).

Sports results, which might mean winning international and national titles, qualifying for various international tournaments, avoiding relegation or being promoted to a higher division, are undoubtedly the most important components of the aggregate result, as these are what various factors of both economic and intangible results depend on.

It is clear that an unforeseen wave of injuries could foil the plans to achieve sports results, just as other unexpected factors could. In other words, by maximising one factor we will not necessarily get closer to our goal, as reaching this goal is influenced by a whole series of factors. This means that other short and long term economic result factors must also be taken into account.

Since the improvement of the financial situation usually has a positive effect on aggregate result, we can assume that the management of any given football enterprise (particularly its financial management) wishes to maximise this and will consider the maximisation of profit the focus of entrepreneurial activity ([10] Zieschang, K.- Klimmer, Ch. 2004). Economic results are closely connected to other result factors. Radical changes of the various result factors could cause undesired effects that might in turn lead to an unforeseeable financial crisis. As a result, players' wages might have to be significantly reduced or assets might have to be sold. In the end, these will have a negative effect on the sports results as well. In the case of relegation to a lower division (which is a significant change), the given football enterprise is forced to face serious economic consequences, which can be lightened through prize indemnity insurance. Even a remarkable sports result, such as winning a championship, could become a negative influencing factor if the club pays extraordinarily high bonuses to players for the title, which could overload the enterprise's budget. Naturally, insurance can be taken out for such cases (which of course costs money).

The intangible result: the success of a football enterprise entails all value factors that are very difficult to quantify using financial-economic or sports result aspects. This includes the image of the football enterprise, the improvement of which usually results in an increased media presence or the improvement of financial positions or the growth of the market value of the enterprise. Of course this also impacts economic results, as an improved image could lead to increased sponsorship. When speaking of intangible results, we should also mention the supporters' strong identification with the club. This strong relationship has a positive impact not only on economic results, but could also boost the achievement of better sports results. 
A football enterprise naturally strives to maximise these intangible results; however, these can only be achieved at the expense of other result factors. Primarily these results could clash with the economic result. If the club's management and owner decide to sign valuable star players and managers regardless of the size of the expenditure, this will obviously have a positive effect on the intangible results and, naturally, sports results as well. It is very likely that in the long-term the enterprise's revenues will also increase. In the mid-term, however, such decisions impose significant financial burdens, which in turn could lead to a serious financial crisis for the club. In professional football - as opposed to other economic fields - it is not customary to prepare a separate plan with respect to image impact for example. Today, the change of image is still an indirect effect of investment. The way of the future is that football enterprises shall directly plan to increase intangible results through certain targeted promotions, e.g. by planning and managing member recruitment, loyalty promotions, etc.

The three main components of the aggregate result and their factors are closely interrelated. For example, the improvement of sports results has a positive impact on economic result, which in turn leads to an increase in television and ticket revenues and the sale of promotional products, but member contributions and revenues from sponsorship deals could also grow. Improving sports results also affects intangible results: the club becomes more respected, supporter ties become stronger and media interest increases. A good economic result has a favourable effect on sports results as the sufficient liquidity provided through profit and appropriate management allows the club to fulfill incentive wages and premium payments without any problems. We should also emphasise that a good economic result has a positive effect on intangible results as well. Opportunities open up to finance supporter projects and clubs as well as significant advertising activity [7] Nagy, Z. I., 2011). A football enterprise acts correctly if it strives to achieve the maximum of the composite result made up of the aforementioned three components.

\section{Legal Forms of Football Clubs}

In Germany, the relationship of associations with incorporated firms may be deemed to be customary already in professional football, promoting the arrangement of business activity. These so-called marketing limited liability companies are essentially similar to business undertakings and they are in general the subsidiaries of associations. However, the real concept of an incorporated firm of football refers more to the outsourcing of football undertakings and of the fields neighbouring football into incorporated firms, or, respectively, to the transformation thereof into incorporated firms. The surviving association operates as a so-called parent association, and it disposes usually over the majority of votes in the incorporated football firm. 
In the event of transformation into or the foundation of an incorporated firm the obtaining operating licence requires compliance also with the requirements made by the League Association, in addition to any other statutory provisions in force. In this respect, first of all the rule of $50 \%+1$ votes must be highlighted in Germany, which must be asserted of course both in the case of the original undertaking and the outsourced marketing company. It is a further important prescription that employees of the business undertaking may not be representatives in the bodies of any other football undertaking. The parent company must dispose over majority representation in the organ of control of the incorporated firm. The right of delegation is within the competence of the parent company. In addition, the statutes of the League Association require from the football companies also a minimum capital amounting to EUR 2.5 million.

However, the election of the legal form of a football association contemplating outsourcing and transformation has not only legal but also economic consequences. Here, particularly, the possibilities of financing should be stressed, which will be enlarged for the football undertakings after the transformation.

In Germany the most frequent incorporated football firms are in the form of the share company, limited liability company or limited partnership, with restricted liability of shareholders.

\section{The Importance of the Share Company in Football}

This is a company having an independent legal personality, in which the company is answerable for its liabilities with the assets (capital wealth) of the company, and which must function in accordance with the Act on Share Companies also in the field of professional football. Its bodies consist of the board of directors, the supervisory board and the general meeting. Any other regulations are asserted, mutatis mutandis, also in the case of football companies, and thus the rules relating to accounting, publicity and the utilisation of profits. The shareholder's equity may be increased, among other ways, through the surrender and exchange of shares, and, respectively, through the issuance of shares and the increase of capital at the stock exchange or over the counter.

Share companies are advantageous, if there is a great need for capital and if it is possible to involve further financers into joint financing. However, in the course of the acquisition of capital, the majority of votes is in each case an indispensable requirement for the parent association, which can be secured through the issuance of registered shares and/or preference shares with restricted transferability [7] Nagy, Z. I., 2011). In the first case the permission of the management of a share company is also required for the acquisition of shares, while the latter ones do not secure any votes for the shareholders, and their issuance may not exceed the sum of the shares already issued (ordinary shares and shares with restricted 
transferability). In this way the formation of an undesirable majority may be prevented; but obviously, the involvement of capital will also be narrowed due to the restrictions, since in the event of contribution of further capital required due to the increase of capital or losses the parent association may incur obligations of payment in order to secure the majority, because the licence rights are possessed in this case by the parent association. The League Association strictly controls compliance with each regulation.

\section{Successful Football Club: Bayern München Share Company}

In the field of German professional football, FC Bayern München is an association, among others, having opted for the form of a share company as a type of incorporated firm. In 2002, the team disposing over the play rights licence, the amateur team No. 1, as well as junior teams A and B and the women's team, were outsourced from the main association, and they were integrated into the marketing subsidiary having been previously founded, and this was then transformed into FC Bayern München AG. Thereby all fields important from the economic viewpoint were integrated into the incorporated firm of football. The non-economic fields and several participations remained with the current company. After that, $10 \%$ of shares were surrendered to a so-called strategic partner (Adidas AG) via share exchange.

The association of FC Bayern München, being the most successful football club of Germany and belonging to the first 5 teams of Europe, can be deemed a model regarding both the transformation of professional football undertakings into market-oriented servicing undertakings, and its significant and salient business and sports results. The club exceeded a turnover of EUR 300 million in the championship 2009/10 for the first time. From among the teams of the German Premier League, it was Bayern München to realise the business opportunities hidden in targeted "merchandising", and it created also the required infrastructure. The leaders who were considered professional managers in the 70s had already decided to search for new resources of revenues, e.g. via opening VIP-boxes. In the 80 s they increased revenues under the leadership of Hoeneß in the fields of merchandising and advertisement, as well as through sharing in the revenues of the German federal television. They modernised the functioning of the club and set up a new organisational structure. The club was a pioneer in the application of merchandising in Germany, but later on this business activity was outsourced into the Sportwerbe LLC, established for this purpose. For the supervisory board an institutionalised system of control was established. In the board of directors the competencies for trade and sports were strictly separated. 
In 2002, with the purpose of establishing an appropriate professional organisation and, last but not least, in order to construct a new stadium, they outsourced the professional football division into the already existing FC Bayern München share company. At that time, the shares were not floated on the stock exchange, but this idea was coming into spotlight more and more (Borussia Dortmund is the single stock exchange company active in the field of football in Germany). Figure 3 shows the ownership structure.

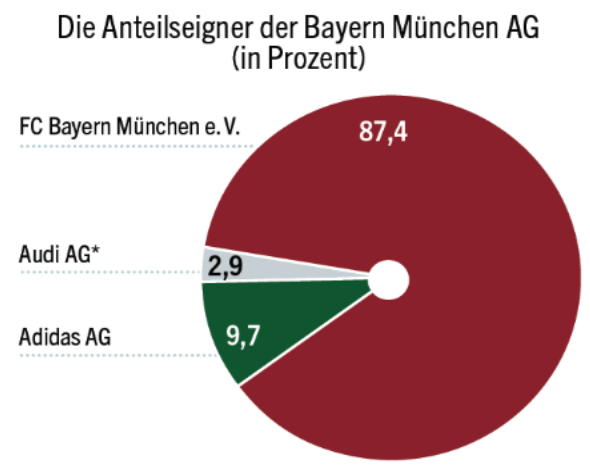

Figure No. 3

Ownership Structure

Source: [6] FC Bayern München WEB site

In accordance with the plans agreed on in advance, Audi AG increased its shareholding in three phases to $9.09 \%$ by July 2011, in this way overtaking the shareholding of Adidas AG. $81.2 \%$ of the shares continued to be held by the association and the registered capital increased to EUR 27.5 million. The share company is the sole owner of Allianz Arena München Stadion LLC, which constructed and is operating the stadium. TSV 1860 München had been the $50 \%$ owner of this LLC until 2006, but it sold its share to FC Bayern München Share Company for EUR 11 million, due to financial problems ([6] FC Bayern München Offizielle WEB-Seite, [7] Nagy, Z. I. 1012).

Records of Bayern München:

- Most Bundesliga titles won: 21

- Most Bundesliga games won (907) and points achieved (3095)

- Most game days on top of the league: 592

- Most average points per game in the Bundesliga: 1.93

- Most Bundesliga goals scored: 3412

- Most consecutive wins in the Bundesliga (19 March-20 September 2005): 15

- Most games won in a club's first Bundesliga season (1965-66): 20

- $\quad$ Biggest lead over second-place finisher (2002-03 $)$ : 16 points 
- Championship with fewest points under the 3-point rule (2000-01): 63

- Championship with the most losses in a season (2000-01): 9

- As a negative record, Bayern's match in Dortmund in the 2000-01 season was the most unfair match in Bundesliga history, with 15 cards having been shown (10 yellow, 1 yellow-red, 2 red), and of those, $12(8,1,1)$ were shown to Bayern players, which is also a record in Bundesliga history.

- Most championships won: 22

- Most cups won: 15

- Most league cups won: 6

- Most doubles won: 8

- Only club to win the double (Bundesliga and cup) twice in a row (2005$\underline{06}$ and $\underline{2006-07)}$

- Only club to win a championship with the men's and women's football department

- Fastest goal in Champions League history: After 10 seconds by Roy Makaay on 7 March 2007 against Real Madrid

- Last club to win the Champions League/European Cup three times in a row: 1974-76

- Highest aggregate win in the UEFA Champions League knockout stage: $12-1$ on 24 February 2009 (5-0) and 11 March 2009 (7-1) against Sporting CP

\section{The Importance of the Limited Liability Company in Football}

The LLC is a preferred form of incorporated firm having legal personality in the field of professional football in Germany, whose regulations are set out in the LLC Act and in commercial law. The registered capital of an LLC is composed of business quotas and this must total at least EUR 25,000. Any other rules are asserted in the same manner as in the case of other LLC's. (In accordance with the prescription of the League Association, the minimum capital amounts to EUR 2.5 million in football!) The equity may be raised through the utilisation of annual profits (in keeping with the restriction of profits linked to a non-profit company, as well as through the increase of the primary stakes and the involvement of new quota holders. The form of LLC is much preferred in other sports, and thus it is wide-spread in the fields of handball and ice hockey. In spite of the fact that the LLC is applied in two main forms, it does not have such an important role in football. One of these forms is a football LLC, which covers all undertakings linked to football and operates as a subsidiary of the parent company with no affection for business. The other form is the LLC having the right of participation 
in the championship, in which case the direction by the parent company is also asserted; but in this case the full right of play (licence) has been assigned to the subsidiary. However, all other fields (marketing, merchandising, etc.) remain with the parent company, or potentially they are outsourced into other companies. The advantage of the second form of LLC is that the permission of play (licence) will be only applied for by the company to use the right of play in the future, and thus it will not be the whole parent company to be forced to comply with the strict licence regulations, in which case such a company may be in a much worse situation than the LLC outsourced for professional football. Let us mention as an example Bayer 04 Leverkusen Fußball - GmbH and Vfl. Wolfsburg-Fußball $\mathrm{GmbH}$. In the case of the first club Bayer AG is the $100 \%$ shareholder, while in the other club Volkswagen AG has a 90\% share. The transformation served in both cases the connection of the football clubs to the parent companies, since in the case of both clubs a long-term linkage to the aforementioned reputable concerns can be experienced. Substantially, these football clubs developed and functioned in parallel with the aforementioned undertakings, and they emerged from their respective corporate sports clubs into League Clubs. This special link between a football club and an undertaking is expressly recognised also by the statutes of the League Association. Accordingly, the presidency of a League Association may resolve outsourcing with $50 \%+1$ votes if given the business undertaking (in our case the aforementioned concerns) had been supporting their branch of football for more than 20 years prior to 1 January 1999 without interruption and to a considerable extent. This support existed in both cases, and in the case of Bayer Leverkusen this had been prevailing already as of 1904 (!).

Notwithstanding the aforementioned special cases there is also a more commercialised and frequent form of football LLCs, which can be resolved by a parent association as majority owner. This solution means essentially the establishment of a subsidiary LLC. An example for this is Borussia Mönchengladbach. This solution may be contemplated if the football undertaking waives the solution of procurement of capital through the stock exchange. Here the number of potential capital owners may be restricted to a predetermined scope of owners, and in this way it is possible to comply with the prescription relating to $50 \%+1$ votes.

\section{A Highly Efficient Legal Form, BVB Dortmund in Germany}

The BVB Borussia Dortmund is a successful limited partnership with shareholder liability. The club was founded by a junior group of 18 of the Catholic Holy Trinity Congregation in 1909. Ball Society, Borussia (BVB), became slowly a modern, professionally managed football club from an amateur football society of peasants and workers. 
Nowadays it is one of the most successful clubs in Germany. It has won the German Championship six times, and it has been the winner of the German Cup two times. In 1968 it has won the Cup of Cup Winners, and in 1997 it was the winner of the Champions League. After that the club decided to transform most parts of the association participating in League I into an incorporated firm quoted also on the stock exchange. As a first step they outsourced in 1999 the business fields, and they founded Borussia Dortmund GmbH \& Co. KG incorporated firm operating through the issuance of shares. Borussia Dortmund Management LLC became the general partner, which was the fully-owned subsidiary of the association. They secured their position in the League Association through the $\mathrm{GmbH} \& \mathrm{Co} . \mathrm{KG}$ in such a manner that the association continued to exercise control over the licence division. In 2002 to the float onto the stock exchange was implemented under the leadership of Deutsche Bank AG. Thus Borussia Dortmund is the single German club admitted to the stock exchange. The price of issuance of the shares was around EUR 11, and the issuance covered 13.5 million shares, which generated revenues amounting to EUR 131 million after the deduction of direct costs amounting to EUR 7.5 million. In addition, other ancillary costs which are difficult to quantify were also been incurred.

At the beginning Borussia played successfully in the championship started in the year of transformation (1999/2000), but later on it almost dropped out for the second time from League I. In order to avoid dropping out they made decisions regarding the football club entailing changes in the staff including the hiring of a coach having achieved successes earlier, as well as further old and committed players. By the end of the championship, the team reached the $11^{\text {th }}$ place. After that the club started intensely purchasing players. They acquired star players through transfer for amounts of double-digit millions in each case. As a result, the team won the Championship for the $6^{\text {th }}$ time in 2002. A decline occurred both in financial stability and the sports results, primarily due to exaggerate purchase of players. The League division operated with a loss of more than EUR 65 million in Season 2003/4 ([1] Bács, Z. - Szima, G., 2012 analyzed the revenues of DVSC (Hungarian club)). The overall debts amounted to EUR 118 million. At that time the $\mathrm{GmbH} \& \mathrm{Co} . \mathrm{KG}$ tried to improve its financial situation through the sale of key players (resulting in significant criticism from the management of the Association), and it sold Westfalenstadion to Commerzbank AG, which had still been $75 \%$ owned upon introduction to the stock exchange. The shares fell deeply below the price of issuance and the experts did not see any hope for an increase in the price even in the long term.

Based on the demand of investors a new management was elected both to the top of the Association and that of the GmbH \& Co. KG. This latter office was vested in the treasurer of the Association. The debts amounted to EUR 98 million in total, threatening seriously the mere existence of Borussia. The restoration was successful. Increases of capital were made several times, the stadium sold was repurchased, all this with the strong support by Morgan Stanley, an American 
investment bank. The net amount of liabilities was reduced to EUR 27 million, and, simultaneously, the proportion of equity increased from $20.7 \%$ to $34.5 \%$ (percentage of equity / balance sheet total).

Under the influence of the experience obtained during the most recent crisis the management of the association - having learnt the consequences of earlier mistakes - reduced the budget of the League team, contributing thereby to the stability of the financial situation ([9] Stöhr, M. 2010). They replaced the old star players transferred abroad in the meantime with young players developed in Borussia's own association. After that, the team played in the medium field of the championship, up to the season 2008/09, when a new coach was engaged. The club rose to the $6^{\text {th }}$ place in the First League, and, in the following Championship, it was the $5^{\text {th }}$ best team, and, as a surprise, the team won the German Championship of 2010/11.

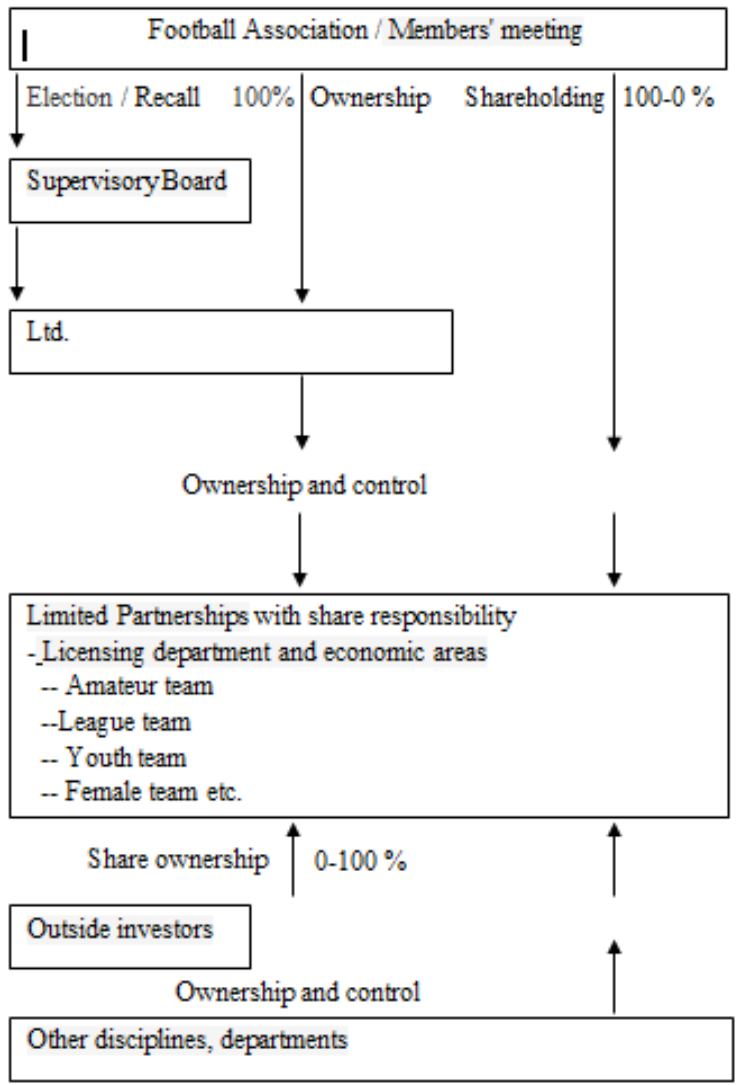

Figure 4

Organisational Schema "Limited Partnerships with share responsibility"

Source: [5] A. Dworak : Finanzierung für Fußballunternehmen 


\section{Conclusions}

In conclusion, the best solution is a Limited Partnership with Restricted Liability of Partners. This is a company having legal personality, in which, as is wellknown, at least one of the partners (the general partner) must bear unlimited and joint and several liability vis-à-vis the creditors. The other owners, who have otherwise interest in the registered capital embodied by the share capital, need not warrant for the liabilities of the company (dormant partners). This is an intermediate legal form that shows the marks of a share company and the personal liability existing in the case of limited partnerships, where the general partner provides for the management of the undertaking. The supervisory board elected by the general meeting of the dormant partners supervises the work of the general partner acting with personal liability, on the one hand, and executes the resolutions of the general meeting, on the other hand, which includes the dormant partners' declaration of acceptance and agreement in the case of more important decisions. Within the scope of legal forms such solutions are interesting for football clubs, since they are vested with the marks of restricted liability covering the general partner of a limited partnership, and at the same time they open a lot of alternative opportunities for finding equity. This limited partnership with restricted shareholders' liability also exists in the case of the forms of GmbH \& Co. KG.

In the case of the legal form operating with the limited liability of a limited partnership, the parent company as general partner may not restrict its personal liability. Thus the association should act simultaneously as general partner and dormant partner if it wishes to retain the aforementioned limited partnership directly as its own property, which is not at all permitted from the legal aspect. Therefore, it is required to insert a limited liability company between the existing association and the limited partnership. This subsidiary LLC is a personally answerable general partner, and it functions as managing director at the same time. The shareholders as dormant partners may consist of the parent company itself and of external investors. This has the advantage, on the one hand, that the parent company is secured by an LLC of limited liability, and, on the other hand, that the possibility exists to increase the dormant partners' share in the limited partnership up to almost $100 \%$, without violating the rules of the League Association relating to majority share. In Germany, $10 \mathrm{GmbH} \& \mathrm{Co}$. KG companies were operating in 2009 in the Licence Leagues (League 1 and 2). See Figure No. 1, page 2.

This legal form offers a reasonable solution for the football clubs for outsourcing the respective fields of licence and business from the form of association into incorporated firms.

Should a football $\mathrm{GmbH} \& \mathrm{Co}$. KG be floated to the stock exchange, it must tolerate a significant handicap as opposed to the companies operating in the form of share company, if it has issued also preference shares without voting right. It is a further problem that the possibility of controlling efficiently the leading bodies of an incorporated firm is missing also in the form of football $\mathrm{GmbH} \& \mathrm{Co}$. KG for the potential investors; they must satisfy themselves with the role of dormant 
partner if they are not members of the parent association. Unfortunately, this may repel potential investors or, at least, it may be taken into account as a significant negative factor upon the valuation of the participation. It is very important in this solution that separation between the rights of general partners and dormant partners should be complied with strictly in practice. It occurs that potential investors frequently link their possible commitments to being involved into the direction and operation of the undertaking, which will of course appear understandable from the aspect of taking care for the safety of investment. In the event of a football $\mathrm{GmbH} \& \mathrm{Co}$. KG, any influence by investors may only be implemented within certain limits. By the way, this is shown by the objection made by the League Association against an investor agreement entered into by TSV 1860 München in the 2009 spring season. The investor agreement contained decisions in respect of persons as conditions for contract, which would have for consequence illicit influence on the side of dormant partner, and/or it would have secured the right of veto in respect of the decisions of the associations.

We can finally state that the outsourcing of significant branches of a football undertaking into the form of an incorporated firm should be deemed as a considerable step forward in comparison with the deficient regulations of the operations of associations, regarding the economic professionality of football clubs, partially from the side of commercial law and partially from the side of shareholding law. Through the introduction of organisational and legal structures that are necessary for the football clubs to be considered professional, there are further positive effects generated for football companies: for example, the football undertaking has to reevaluate its assets due to the transformation, which usually has a positive effect on the proportion of equity. This is still complemented by the fact that in the event of incorporation, the equity will increase through the accumulation of profits based on the compulsory regulations of the application of profits. Incorporation allows external investors to get involved in football undertakings, which may be implemented through investment into the respective business quotas of an LLC or a share company or a limited partnership. Here we must stress above all the obligation of publicity and information which makes the incorporated firms transparent for the potential investors of debt capital, and allow for reliable credit ratings and risk assessments. Furthermore, it is also advantageous that incorporated football firms operate similarly to incorporated firms functioning in other fields, from the point of view of the protection of creditors. Finally, a large palette of alternative financing is available for incorporated firms which which are not available in the event of the original legal form and organisational structure of associations. Nevertheless, it should be underlined that in the event of the use of the form of the incorporated football firm, it is about the transformation and change of the organisational unit of execution and not about a total abandonment of the form of association. The form of association will continue to be the main form for football undertakings and a fundamental solution for the procurement of capital. Due to the reasons above, professional football is partially an exemption in this respect. 


\section{References}

[1] Bács, Z. - Szima, G.: Values of the Club Building (and What is Behind It). International Conference on Tourism and Spoertmanagement. Universitas Debreceniensis. 2012, pp. 1-12

[2] Bott, S.: Internationalisierungsstrategien von nationalen Fußballigen, 1. Auflage, Books on Demand GmbH, Norderstedt. 2007, pp. 1-143

[3] Bundesliga Offizielles WEB-Seite www.bundesliga.de, 2011

[4] Bundesligareport 2011:

http://www.bundesliga.de/media/native/autosync/dfl_bl_report_2011_fin_1 50dpi_deutsch.pdf

[5] Dworak, A.: Finanzierung für Fußballunternehmen, Erich Schmidt Verlag, Berlin 2010, pp. 1-387

[6] FC Bayern München, WEB-Seite 2011

[7] Nagy, Z. I.: Finances of the Professional Football Enterpises. Journal Article, Danube/Law and Economics Review. Volume 3, Issue Number 1, 2012. 03. 31. pp. 53-69

[8] Schmid, V.: Unternehmensführung im Profifußball, Erich Schmidt Verlag Berlin 2004

[9] Stöhr, M.: Unternehmensführung im deutschen Profifußball, Seminararbeit bei Dr. Nagy, Z. I. Obudai Egyetem, Budapest 2010, pp. 1-26

[10] Zieschang, K. / Klimmer, Ch. (Hrsg.): Unternehmensführung im Profifußball, Erich Schmidt Verlag, Berlin 2004, pp. 1-229

[11] Borbély, A.: Országos Sporttudományi Kongresszus, Magyar Sporttudományi Szemle, 2012/2. Budapest 2012, pp. 6-12 